Heike K. Lotze $\cdot$ Karsten Reise $\cdot$ Boris Worm

Justus van Beusekom · Mette Busch · Anneli Ehlers

Dirk Heinrich · Richard C. Hoffmann · Poul Holm

Charlotte Jensen · Otto S. Knottnerus

Nicole Langhanki · Wietske Prummel

Manfred Vollmer · Wim J. Wolff

\title{
Human transformations of the Wadden Sea ecosystem through time: a synthesis
}

Received: 8 September 2004/ Revised: 15 October 2004/ Accepted: 18 October 2004/ Published online: 29 January 2005

(C) Springer-Verlag and AWI 2005

\begin{abstract}
Today's Wadden Sea is a heavily human-altered ecosystem. Shaped by natural forces since its origin 7,500 years ago, humans gradually gained dominance in influencing ecosystem structure and functioning. Here, we reconstruct the timeline of human impacts and the history of ecological changes in the Wadden Sea. We then discuss the ecosystem and societal consequences of observed changes, and conclude with management implications. Human influences have intensified and multiplied over time. Large-scale habitat transformation over the last 1,000 years has eliminated diverse terrestrial, freshwater, brackish and marine habitats. Intensive exploitation of everything from oysters to whales has depleted most large predators and habitat-building species since medieval times. In the twentieth century, pol-
\end{abstract}

Communicated by H.K. Lotze and K. Reise

H. K. Lotze $\cdot$ K. Reise · J. van Beusekom · W. J. Wolff Alfred Wegener Institute for Polar and Marine Research, Wadden Sea Station Sylt, 25992 List, Germany

H. K. Lotze · B. Worm · A. Ehlers · N. Langhanki Leibniz Institute for Marine Science, Düsternbrooker Weg 20, 24105 Kiel, Germany

M. Busch

Nationalmuseet, c/o Vikingeskibsmuseet,

Vindeboder 12, Roskilde, 4000, Denmark

D. Heinrich

Institut für Haustierkunde, University of Kiel,

Olshausenstr. 40, 24118 Kiel, Germany

R. C. Hoffmann

Department of History, York University,

4700 Keele St., Toronto, ON, M3J 1P3, Canada

P. Holm · C. Jensen

Centre for Maritime and Regional History,

University of Southern Denmark,

Niels Bohrs Vej 9-10, 6700, Esbjerg, Denmark lution, eutrophication, species invasions and, presumably, climate change have had marked impacts on the Wadden Sea flora and fauna. Yet habitat loss and overexploitation were the two main causes for the extinction or severe depletion of 144 species $(\sim 20 \%$ of total macrobiota). The loss of biodiversity, large predators, special habitats, filter and storage capacity, and degradation in water quality have led to a simplification and homogenisation of the food web structure and ecosystem functioning that has affected the Wadden Sea ecosystem and coastal societies alike. Recent conservation efforts have reversed some negative trends by enabling some birds and mammals to recover and by creating new economic options for society. The Wadden Sea history provides a unique long-term perspective on ecological change, new objectives for conservation,

\section{O. S. Knottnerus}

Uiterburen 47, EC Zuidbroek, 9636,

The Netherlands

W. Prummel

Groningen Institute of Archaeology,

Poststraat 6, Groningen, 9712 ER,

The Netherlands

M. Vollmer

Common Wadden Sea Secretariat,

Virchowstrasse 1, Wilhelmshaven,

26382, Germany

W. J. Wolff

Department of Marine Biology,

University of Groningen,

PO Box 14, 9750 AA Haren, The Netherlands

Present address: H. K. Lotze ( $\square)$

Department of Biology, Dalhousie University, Halifax,

Nova Scotia, B3H 4J1, Canada

E-mail: hlotze@dal.ca

Tel.: + 1-902-4942478

Fax: + 1-902-4943736 
restoration and management, and an ecological baseline that allows us to envision a rich, productive and diverse Wadden Sea ecosystem and coastal society.

Keywords Environmental history · Human impacts · Shifting baselines $\cdot$ Ecosystem consequences .

Conservation

\section{Introduction}

When the Wadden Sea was created approximately 7,500 years ago, humans were already there. As Stone Age hunter/gatherers they hunted aurochs, elk, red deer, wild boar, bear and other game in the woodlands, and birds and seals along the coast. They fished in fresh, brackish and salt water, harvested shellfish, and collected eggs, fruits and seeds (Bantelmann 2003). These hunter/gatherers, as well as early farmers and permanent settlers from about 5,500 years ago onwards, used the resources of their environment but did not interfere with the development of the landscape or seascape for thousands of years. This situation began to change around 2,500 years ago in the south-western Wadden Sea, from where human-induced changes gradually spread eastwards and northwards along the coast. As people learned to modify the landscape in order to protect themselves and their land from the influence of the sea, they began to transform the coastal wetlands, gradually separating the land from the sea. And they learned to use every resource that the Wadden Sea offered effectively. Over time, human influences began to dominate the Wadden Sea ecosystem.

In this paper, we attempt to synthesize all available information in order to reconstruct the timeline of human impacts and the history of ecological changes in the Wadden Sea. This synthesis is based on the eight previous papers of this volume of Helgoland Marine Research, providing an interdisciplinary overview on the history of human settlement (Knottnerus 2005), habitat transformation (Reise 2005), exploitation in a European (Hoffmann 2005) and regional context (Holm 2005; Wolff 2005), eutrophication (van Beusekom 2005), and the history of changes in the Wadden Sea fauna and flora (Lotze 2005; Prummel and Heinrich 2005). We then ask what the consequences of observed changes are for biodiversity, and food-web and ecosystem structure and functioning, and what this means to society. Finally, we discuss what we can learn from the history of the Wadden Sea for conservation, restoration and management.

\section{Timeline of human impacts}

Table 1 presents a general timeline of change for the Wadden Sea from 8000 B.C. to A.D. 2000. We summarized the major cultural and economic periods, the associated human impacts per period, and the major ecological changes in the Wadden Sea fauna and flora. It is important to note that the transitions between periods were gradual and there were many regional differences in the timing of new human influences (see Regional differences section below). However, the general sequence of intensification and multiplication of human impacts over time and space (Table 1) was similar.

\section{Cultural and economic periods}

Over the past 10,000 years, coastal people have developed from hunter/gatherer tribes to being part of a global society (Table 1). There were four main stepping stones in this transition. First, with the introduction of agriculture and permanent settlement in the Neolithic, people adapted to and modified the landscape to create farmland and protect their homes. Former exploitation of wild resources for subsistence was replaced by artisan exploitation to enrich local food production. During the Roman, Early Medieval and Viking Ages, trade and Frisian commerce evolved, but basic living conditions and technologies remained largely unchanged. Second, with the creation of a society and market economy in High and Late Medieval times people started to systematically transform the landscape and to commercialize resource exploitation. The growing population had a growing demand for food and agricultural land, but also an increasing demand for other goods, that drove exploitation of living resources for trade, fashion, luxury markets and prestige (Hoffmann 1996, 2005; Lotze 2004). These trends did not change much but were intensified in the Early Modern period. Third, with industrialization, large-scale mechanization and urbanization in the Late Modern and Early Global periods people constructed and destroyed the landscape and seascape. The resource-based economy culminated with massive, industrial-scale agriculture and fisheries. Moreover, World Wars I and II significantly affected the Wadden Sea region, with new infrastructures and societal changes. Fourth, with the globalization in the Late Global period the resource-based economy shifted to a service-based and tourism economy. This transition still causes many conflicts between traditional and new ways of 'using' the Wadden Sea ecosystem. On the one hand, industrial-scale fisheries and agriculture still aim to enhance local exploitation and food production, and together with other industrial activities multiply the range and scale of human impacts. On the other hand, depletion and collapse of species and degradation of living conditions have led to conservation and protection efforts that also support the tourism industry.

An underlying trend over all periods is the continuing human population growth. Although periods of depopulation, stagnation and setbacks have occurred (Knottnerus 2005), human numbers have mostly increased exponentially over time, especially since the Middle Ages. The coastal population doubled from 15-25 to $30-50$ inhabitants $\mathrm{km}^{-2}$ during the sixteenth 
Table 1 Timeline of human impacts and ecological changes by cultural period in the Wadden Sea regionContinuous developments are listed at their climax period. For more details and for regional differences between the Dutch, Danish, and German Wadden Sea refer to text (based on Hoffmann 1996, 2005; Haywood 1997; Vollmer et al. 2001; Huntley et al. 2002; Bantelmann 2003; Holm 2005; Knottnerus 2005; Lotze 2005; Reise 2005; Prummel and Heinrich 2005; van Beusekom 2005; Wolff 2005)

\begin{tabular}{|c|c|c|c|c|c|c|}
\hline & & & & Human impacts & & \\
\hline Time & Cultural Period & Economy & Exploitation & Habitat change & Other impacts & $\begin{array}{c}\text { Ecological } \\
\text { changes }\end{array}$ \\
\hline \multicolumn{7}{|c|}{ Palaeolithic } \\
\hline \multirow{2}{*}{$\begin{array}{c}40000- \\
10000 \mathrm{BP}\end{array}$} & Ice Age & & & & & \\
\hline & Mesolithic & Hunter-gatherer & \multicolumn{2}{|l|}{ Subsistence } & & Gradual decrease \\
\hline \multirow[t]{2}{*}{$\begin{array}{c}8000- \\
4900 \mathrm{BC}\end{array}$} & $\begin{array}{l}\text { Sparse mesolithic } \\
\text { occupation, Wadden } \\
\text { Sea creation ca. } 5500 \\
\text { BC }\end{array}$ & & $\begin{array}{l}\text { Hunting (game, birds, } \\
\text { seals), fishing (fish, } \\
\text { shellfish), gathering } \\
\text { (eggs, feathers, plants) }\end{array}$ & & & $\begin{array}{l}\text { Large terrestrial game } \\
\text { (e.g. aurochs, elk, bear) }\end{array}$ \\
\hline & Neolithic / Bronze Age & Agriculture & \multicolumn{2}{|r|}{ Adaptation } & & Gradual decrease \\
\hline \multirow[t]{2}{*}{$\begin{array}{l}4900- \\
800 \mathrm{BC}\end{array}$} & $\begin{array}{l}\text { Neolithic time introduced } \\
\text { ca. 4200-2800 BC, } \\
\text { Bronze Age (2100-800 } \\
\text { BC) }\end{array}$ & $\begin{array}{l}\text { Cattle grazing, arable } \\
\text { farming }\end{array}$ & $\begin{array}{l}\text { Hunting (game, birds, } \\
\text { seals), fishing (fish, } \\
\text { shellfish), gathering } \\
\text { (eggs, feathers, plants) }\end{array}$ & $\begin{array}{l}\text { Settlement of river banks } \\
\text { and heights, forest } \\
\text { removal, marshland } \\
\text { grazing }\end{array}$ & & $\begin{array}{l}\text { Large terrestrial game } \\
\text { (e.g. aurochs, elk, bear) }\end{array}$ \\
\hline & \multicolumn{2}{|l|}{$\begin{array}{c}\text { Roman / Early } \\
\text { Medieval }\end{array}$} & \multicolumn{3}{|c|}{ Modification } & Disappearance \\
\hline \multirow[t]{2}{*}{$\begin{array}{l}800 \mathrm{BC}- \\
\text { AD } 1050\end{array}$} & $\mid \begin{array}{l}\text { Pre-Roman and Roman } \\
\text { Iron Age (800 BC - AD } \\
400) \text {, Early Medieval and } \\
\text { Viking Age (AD 400- } \\
1050)\end{array}$ & $\begin{array}{l}\text { Long-distance trade, } \\
\text { Frisian commerce, } \\
\text { agriculture, basic } \\
\text { technology same as } \\
\text { previous }\end{array}$ & $\begin{array}{l}\text { Hunting (game, birds, } \\
\text { seals), fishing (fish, } \\
\text { shellfish), gathering } \\
\text { (eggs, feathers) }\end{array}$ & $\begin{array}{l}\text { Settlement of marshes, } \\
\text { dwelling mounds, } \\
\text { ditches }\end{array}$ & & $\begin{array}{l}\text { Large terrestrial game } \\
\text { (e.g. elk, bear), perhaps } \\
\text { some large birds } \\
\text { (pelican, flamingo) }\end{array}$ \\
\hline & High / Late Medieval & Market & Commercial & Transformation & River pollution & Decline \\
\hline \multirow[t]{4}{*}{$\begin{array}{l}\text { AD } 1050 \\
-1500\end{array}$} & Society, Middle Ages & $\begin{array}{l}\text { Exponential expansion } \\
\text { of exchange sector, } \\
\text { Hanseatic power, } \\
\text { agricultural technique } \\
\text { and extent increased }\end{array}$ & $\begin{array}{l}\text { Commercialization of } \\
\text { fishing (herring, oyster), } \\
\text { bird hunting, whaling, } \\
\text { seagrass harvest for } \\
\text { dike building }\end{array}$ & $\begin{array}{l}\text { Systematic embankment } \\
\text { and drainage of coastal } \\
\text { marshes and inland } \\
\text { mires, low dikes, dams, } \\
\text { and ditches, peat } \\
\text { exploitation }\end{array}$ & $\begin{array}{l}\text { Sewage, sedimentation, } \\
\text { siltation }\end{array}$ & $\begin{array}{l}\text { Large diadromous fish, } \\
\text { large birds, wetlands; } \\
\text { disappearence of grey } \\
\text { seals, aurochs }\end{array}$ \\
\hline & Early Modern & Modern & Intensification & Separation & River pollution & Decline \\
\hline & Modernization & $\begin{array}{l}\text { Integration into modern } \\
\text { world economy, } \\
\text { agriculture and maritime } \\
\text { trade greatly intensified, } \\
\text { islanders involved in } \\
\text { shipping, trading, } \\
\text { whaling }\end{array}$ & $\begin{array}{l}\text { Intensified fishing, } \\
\text { whaling, hunting of birds, } \\
\text { seals, porpoise, } \\
\text { collection of eggs, } \\
\text { feathers, regulations } \\
\text { imposed on declining } \\
\text { resources }\end{array}$ & $\begin{array}{l}\text { Separation and } \\
\text { homogenization of } \\
\text { landscape, modern } \\
\text { dikes, many forelands } \\
\text { embanked, river } \\
\text { damming, harbour } \\
\text { building }\end{array}$ & $\begin{array}{l}\text { Sewage, waste water, } \\
\text { sedimentation, siltation }\end{array}$ & $\begin{array}{l}\text { Large groundfish, birds, } \\
\text { wetlands; disappearance } \\
\text { of large whales }\end{array}$ \\
\hline & Late Modern & Industrial & Peak and decline & Construction & Estuarine pollution & Decline \& Loss \\
\hline \multirow[t]{2}{*}{$\begin{array}{l}\text { AD } 1800 \\
-1900\end{array}$} & $\begin{array}{l}\text { Industrialisation, } \\
\text { Urbanisation }\end{array}$ & $\begin{array}{l}\text { High days of large-scale } \\
\text { modern agriculture and } \\
\text { coastal shipping, } \\
\text { industries grew }\end{array}$ & \begin{tabular}{|l|} 
Traditional fisheries \\
peaked and declined, \\
new fisheries developed, \\
bird exploitation peaked, \\
whaling ceased
\end{tabular} & \begin{tabular}{|} 
Large embankments, \\
canalization of estuaries, \\
river damming, \\
transportation routes
\end{tabular} & $\begin{array}{l}\text { Sewage, waste water, } \\
\text { sedimentation, siltation }\end{array}$ & $\begin{array}{l}\text { Most birds, diadromous } \\
\text { fish, large groundfish, } \\
\text { oysters, wetlands }\end{array}$ \\
\hline & Early global & Global & Industrial & Destruction & Coastal pollution & Loss \\
\hline \multirow[t]{2}{*}{$\begin{array}{l}\text { AD } 1900 \\
-1970\end{array}$} & Mechanisation, warfare & $\begin{array}{l}\text { Large-scale } \\
\text { mechanisation of } \\
\text { agriculture and fishing }\end{array}$ & $\begin{array}{l}\text { Industrial-scale fisheries, } \\
\text { trawling }\end{array}$ & $\begin{array}{l}\text { Agricultural landscape } \\
\text { stripped to essentials, } \\
\text { large loss of brackish } \\
\text { waters (Zuiderzee), } \\
\text { seafloor trawling, } \\
\text { shoreline petrification }\end{array}$ & $\begin{array}{l}\text { Sewage, waste water, } \\
\text { artificial fertilizer, } \\
\text { pesticides, DDT, heavy } \\
\text { metals, sedimentation, } \\
\text { siltation }\end{array}$ & $\begin{array}{l}\text { Loss of large predators } \\
\text { (many birds, mammals, } \\
\text { fish at low levels), } \\
\text { habitat-building species, } \\
\text { wetlands }\end{array}$ \\
\hline & Late Global & Tourism & $\begin{array}{l}\text { Collapse and } \\
\text { conservation }\end{array}$ & Protection & Multiple impacts & Invasion and recovery \\
\hline $\begin{array}{l}\text { AD } 1970 \\
-2000\end{array}$ & Globalisation & $\begin{array}{l}\text { Increased activities, boat } \\
\text { traffic, infrastructure }\end{array}$ & $\begin{array}{l}\text { Artisan inshore fishery, } \\
\text { shellfish cultures, } \\
\text { industrial offshore } \\
\text { fishery collapse, species } \\
\text { protection }\end{array}$ & $\begin{array}{l}\text { Coastal defence, habitat } \\
\text { protection, restoration } \\
\text { efforts, National parks }\end{array}$ & $\begin{array}{l}\text { Artificial fertilizer, heavy } \\
\text { metals, pesticides, } \\
\text { PCBs, TBT, climate } \\
\text { change, exotic invasions }\end{array}$ & $\begin{array}{l}\text { Impacts of invaders, } \\
\text { harmful algal blooms, } \\
\text { algal masses, diseases; } \\
\text { recovery of some birds } \\
\text { and seals }\end{array}$ \\
\hline
\end{tabular}


century, and again increased to $75-100 \mathrm{~km}^{-2}$ during the nineteenth century. Today, the coastal population around the Wadden Sea consists of 5 million in urban and 1-1.5 million in rural areas (Vollmer et al. 2001).

\section{Exploitation}

The history of exploitation is a history of intensification, spatial expansion, serial resource depletion and collapse (Table 1, see also Hoffmann 2005; Holm 2005; Lotze 2005; Wolff 2005). Subsistence and artisan exploitation from 8000 B.C. to A.D. 1050 put a continuous but low pressure on the marine resources of the Wadden Sea. This changed dramatically with the commercialization of many fisheries, bird hunting, whaling, peat exploitation, and other resource uses in the High and Late Medieval periods. Since then, effort as well as efficiency and destructive power of exploitation techniques continuously increased during the following centuries. This intensification ultimately led to peaks and declines of many traditional resources in the nineteenth and early twentieth centuries. As a response, some fisheries (e.g. sturgeon, salmon, rays) collapsed, while others (e.g. herring, groundfish) were industrialized and expanded into offshore regions. In inshore regions, new fisheries developed, in particular for invertebrates, traditional mussel and oyster harvest was replaced by dredging, and exploitation of wild mussel beds was replaced by cultivation of native mussels and exotic oysters. Hunting of birds for food and feathers, egg collection, and hunting of mammals ceased in the twentieth century when many species had reached very low population levels or were extinct. Regulations to control high exploitation pressure such as quotas, closed seasons, privatization and gear restrictions were first imposed in the Middle Ages (see also Lotze 2004, 2005). These measures could slow down, but ultimately not prevent, decline and collapse of traditional resources because of growing human demand and economic pressures. Serious conservation efforts were first implemented in the twentieth century. However, today industrial-scale fisheries still exist offshore, and inshore fisheries for mussels, cockles, flatfish and shrimp remain unselective and destructive.

\section{Habitat change}

The history of habitat alteration is also a history of intensification and spatial expansion (Table 1; see also Knottnerus 2005; Reise 2005). First, people adapted to the marsh region of the Wadden Sea by simply using natural elevations for settlement and agriculture and the lower marshlands for grazing. This situation gradually changed when people started to modify the landscape locally in order to directly settle the marshes. Dwelling mounds and ditches helped to secure their homes and drain the land. This pattern of small-scale modification

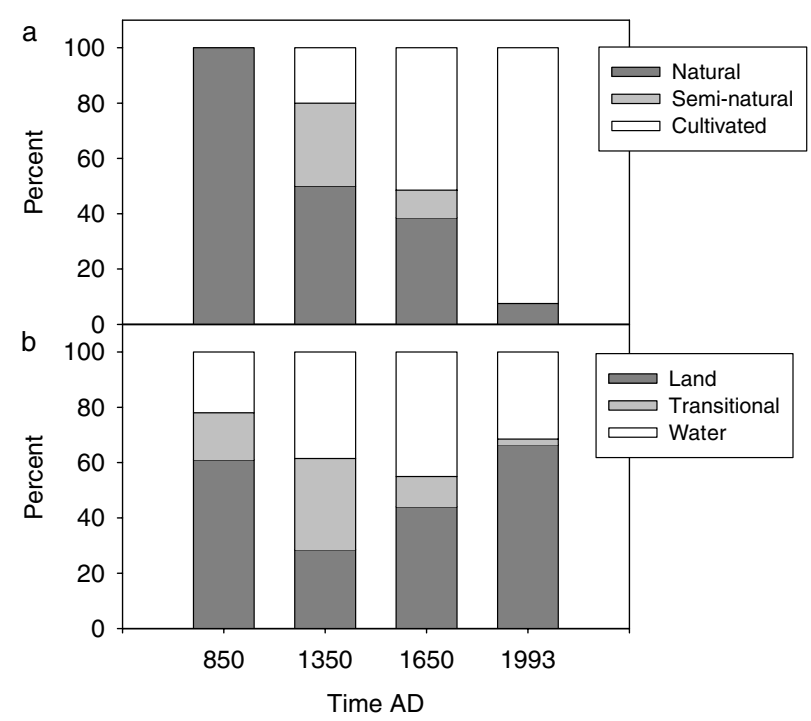

Fig. 1 Human influence on the landscape in the Ijsselmeer region (former Zuiderzee) in the Netherlands A.D. $850-1993$ by building dikes, draining lakes and lowering groundwater tables: a gives the degree of habitat 'naturalness', and b shows the composition of major landscape types. Percentage area estimates were derived from paleographic maps (adapted from van Eerden 1997)

changed radically after A.D. 1000. Systematic embankment and drainage of coastal marshes and inland moors led to large-scale transformation of the landscape. Whereas medieval dikes were too low to prevent large floods and land loss, higher and stronger dikes that finally separated the land from the sea were built in the Modern period. Many wetlands disappeared and the landscape was homogenized. This gradual loss of natural habitats and wetlands is illustrated in Fig. 1. For parts of the Netherlands, van Eerden (1997) estimated the extent of landscape types and land use patterns over time by analyzing paleographic maps. The estimates indicate that within 1,000 years the former natural landscape has been almost completely transformed to cultivated land (Fig. 1a). Thereby, a mosaic of wetland or transitional habitats disappeared (Fig. 1b) and was replaced by agricultural fields that were clearly separated from the sea by a continuous dike-line with strong seaward defences. Transitional habitats such as those of the former salt marshes and gullies became squeezed out, and the large brackish Zuiderzee was dammed and converted into a freshwater lake.

In the industrial periods of the nineteenth and early twentieth centuries, the landscape was more and more redesigned to fulfil human needs: large remaining bays were embanked, estuaries canalized and rivers dammed. The destruction of the natural landscape expanded into the seascape in the twentieth century, when trawling destroyed many seafloor habitats. In the last third of the twentieth century a turning point was reached, as habitat protection and restoration efforts were initiated on a large scale. 
Other impacts

Exploitation and habitat change remained the major human impacts on the Wadden Sea ecosystem for millennia. Changes in sediment and nutrient loads probably started in the Middle Ages when dike building, wetland draining, land reclamation and erosion of peat lands began, and sewage loads of the growing population increased. A tentative reconstruction of nutrients and phytoplankton dynamics in an idealised European coastal area suggests impacts due to changes in land use as early as 1,000 years ago (Billén and Garnier 1997). Resulting problems with water quality were first recognized in rivers far inland in the High Middle Ages (Hoffmann 1996), but gradually moved towards estuaries and the coastal zone in the nineteenth and twentieth centuries (Table 1). However, drastic increases in nutrient loads and large-scale eutrophication only occurred after 1950, when artificial fertilizers became of widespread use in modern agriculture (De Jonge et al. 1993; van Beusekom 2005). Compared to pre-industrial levels, total nitrogen load of rivers probably increased eightfold and primary production and remineralisation in the coastal zone five- to sixfold (van Beusekom 2005). Dredging of estuaries increased the suspended matter load (De Jonge 1983), and dumping of dredged material may have contributed to increased suspended matter concentrations in the Wadden Sea (De Jonge and de Jong 2002). Waste water discharge from industrial activities into rivers and estuaries occurred probably since modern times, but again loading of pesticides (e.g. DDT), organochlorines (e.g. PCB), endocrine disruptors (e.g. TBT) and heavy metals increased markedly after 1950 (Wolff 1992; Smetacek et al. 2002). Similarly, anthropogenic climate change (warming, increased UV radiation) and exotic invasions have become severe problems during recent decades (Beukema et al. 1990; Reise et al. 2005). Thus, not only intensification but also a multiplication of human impacts have occurred over time.

\section{Regional differences}

A detailed description of regional differences in the history of change can be found in Vollmer et al. (2001). As a general trend, new techniques for wetland habitation and exploitation were often first invented or introduced in the south-western part of the Wadden Sea and spread from there along the coast eastward and northward, often facilitated by people migrating up the coast in search of new land to settle (Vollmer et al. 2001; Bantelmann 2003; Knottnerus 2005). For example, duck decoys were a new technology used to catch large numbers of ducks effectively. They were first mentioned in Holland in the fifteenth century, reached Friesland in the sixteenth century, Nordfriesland in the eighteenth century, and the Danish island of Fanö in 1830. On the other hand, the Danish and north Frisian parts of the Wadden Sea were influenced by Scandinavian cultures
(Bantelmann 2003). The greatest regional difference was in the history of marshland settlement and diking in the Danish compared to the Dutch and German (see Table 1) Wadden Sea. Most diking in Denmark only occurred in the nineteenth and twentieth centuries and undiked fragments still exist today (Vollmer et al. 2001; Holm 2005). The major reason for this late embankment was the narrow extent of coastal marshes that made marshland settlement unnecessary for a long time. Until the late nineteenth century, settlements remained on natural elevated heights while marshes were used for grazing and hay-making (Vollmer et al. 2001).

\section{History of ecological changes}

\section{Early decrease and disappearance}

Large terrestrial mammals (e.g. aurochs, elk, bear) and perhaps some large birds (pelican, flamingo) were hunted in the Wadden Sea area and the adjacent sandy areas during the earliest periods of human occupation (until about A.D. 1050; Table 1). These species, with the exception of the Dalmatian pelican, could be recognized in the archaeological evidence (Wolff 2000a, 2000b; Bantelmann 2003; Prummel and Heinrich 2005; Lotze 2005). It is likely that these species gradually decreased in numbers due to hunting, which started in the Mesolithic, and habitat destruction, which started in the Neolithic, before they disappeared (Table 1). However, it is not possible to judge whether their disappearance was directly and solely caused by human impacts in Wadden Sea, or whether it was the consequence of large-scale population declines and contractions throughout Europe. For aurochs and elk, habitat loss may have contributed to their disappearance in addition to direct exploitation (Bantelmann 2003; Prummel and Heinrich 2005). Pelicans and flamingos possibly suffered from exploitation and habitat loss around the Mediterranean even in Roman times and throughout Europe in Medieval times (Plinii Secundi 1513; Magnus 1555; Hughes 1996). In contemporary Europe, breeding populations of pelicans only occur in the Danube delta, and of flamingos in a few sites around the Mediterranean (Bauer and Glutz von Blotzheim 1966).

\section{Long-term decline}

During Medieval and Modern times, a period of gradual decline in many large diadromous fish (e.g. sturgeon, salmon), groundfish (e.g. haddock, cod, rays), waterbirds (e.g. herons, cranes, spoonbills, cormorants, ducks and geese), and marine mammals (e.g. grey seals, large whales) occured. This trend culminated in the industrial and global periods of the nineteenth and twentieth centuries (Table 1; see Lotze 2005). However, large whales had already disappeared in Early Modern times 
as a result of high exploitation pressure throughout the North Atlantic (De Smet 1981), and grey seals disappeared in the Middle Ages because of exploitation and disturbance in the Wadden Sea region itself (Wolff 2000b; Prummel and Heinrich 2005). The commercialization and intensification of exploitation inside and outside the Wadden Sea was one major driver for declines, but for species depending on wetlands, river or estuarine habitats, habitat loss, destruction and degradation also played a significant role. By the late nineteenth/early twentieth century, many species had reached very low levels.

\section{Loss and extinctions}

In the twentieth century, highly efficient but destructive exploitation techniques resulted in the loss or severe depletion of most remaining large predators (marine mammals, birds, fish) and the destruction of habitatbuilding species on the seafloor (Table 1). Once-abundant oyster banks were lost completely, while relicts of Sabellaria reefs survived. In addition, the remaining salt and reed marshes, peatlands and wetlands were transformed, and sublittoral eelgrass beds were eliminated by disease and never recovered. At the end of the twentieth century, 144 species $(\sim 20 \%$ of total macrobiota) were listed on the Trilateral Red List of threatened species (Fig. 2b; von Nordheim et al. 1996). Of these, 21 species were considered extinct in the twentieth century, while another four species had become extinct in earlier cen-

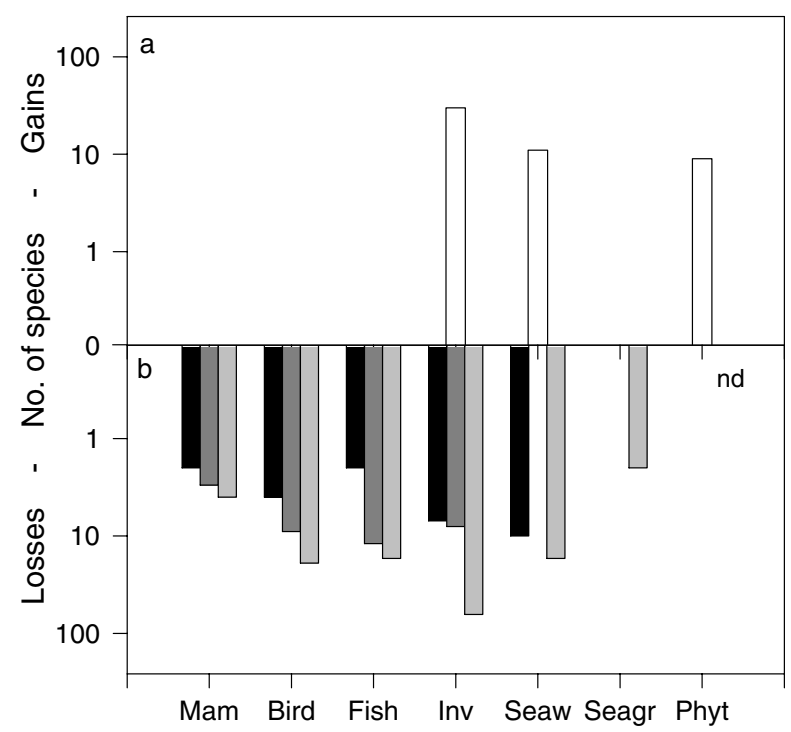

Fig. 2 Changes in biodiversity. Number of species (log scale) that became a newly introduced (white), and b entirely extinct (black), regionally or temporally extinct (dark grey) or threatened (light grey) in the Wadden Sea. Data are presented for marine mammals (Mam), birds (Bird), fish (Fish), invertebrates (Inv), seaweeds (Seaw), seagrasses (Seagr) and phytoplankton (Phyt). There were no data $(n d)$ on extinct or threatened phytoplankton. Data from von Nordheim et al. (1996); Wolff (2000a, 2000b); Lotze (2005); Reise et al. (2005) turies (Wolff 2000a, 2000b; Lotze 2005). Thirty-two species were listed as extirpated regionally or temporally (Fig. 2b).

The most important factors that caused or contributed to species extinctions were habitat loss $(70.2 \%$ of extinctions) and exploitation (54.4\%), followed by pollution $(8.8 \%)$, climate change and disease $(1.8 \%$ each $)$ (Fig. 3). So far, no known case of extinction has been caused by invasive species. More than half of the extinctions were caused by only a single factor, either by habitat loss $(38.6 \%)$ or exploitation $(21.1 \%)$. In the remaining cases, two or more human impacts acted in combination. Extinctions in marine mammals, birds and fish have been, to a larger extent, caused by exploitation, while extinctions in invertebrates and plants have mainly been caused by habitat loss (Fig. 3).

\section{Recovery, increase and invasion}

In the second half of the twentieth century, conservation efforts led to the recovery of several bird species as well as grey and harbour seals (Lotze 2005). In some species, exponential increases have been observed after exploitation was prohibited and important breeding, feeding or staging habitats were protected. These high population growth rates indicate that the species were, and in some cases still are, far from their carrying capacity [e.g. seals (Reijnders 1992); birds (De Jonge et al. 1993)]. Also, in several species setbacks occurred during the recovery process due to disease [e.g. seal epidemic (De Jonge et al. 1993)], food shortage [e.g. eiders (Camphuysen et al. 2002)] or pollution [e.g. eiders, spoonbills, terns, seals, porpoise (Reijnders 1986; Wolff 1992; De Jonge et al. 1993)].

Increases have also been observed in species that are favoured by human influences. In the course of eutro-

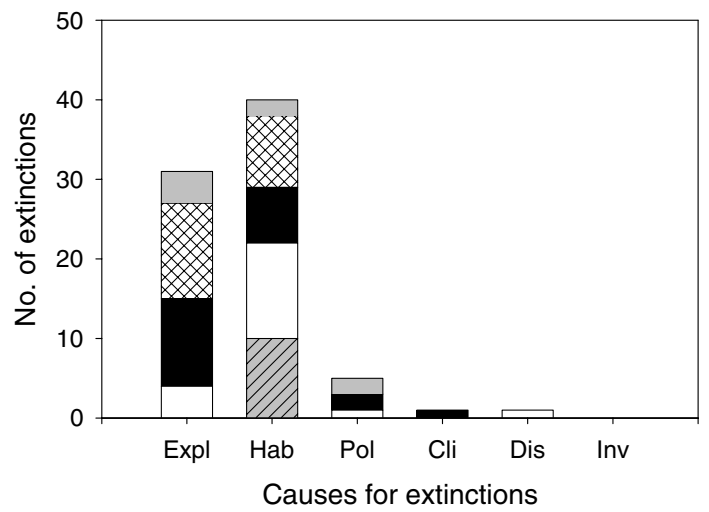

Fig. 3 Causes for species extinctions in the Wadden Sea. Number of extinctions that were fully or partly caused by exploitation $($ Expl), habitat change or destruction $(\mathrm{Hab})$, pollution ( $\mathrm{Pol}$ ), climate change $(C l i)$ or disease (Dis). There is no known case of extinction caused by an invasive species (Inv). Different shades refer to marine mammals (light grey), birds (cross-hatched), fish (black), invertebrates (white), and seaweeds (grey hatched). Data from von Nordheim et al. (1996); Wolff (2000a, 2000b); Lotze (2005) 
phication, the diversity and abundance of suspension feeders, especially sediment dwellers such as polychaetes, has increased (Reise et al. 1989; Lotze 2005). Also, green macroalgae and phytoplankton have increased, sometimes causing mass developments and harmful or nuisance algal blooms (Lotze 2005). Moreover, the number of exotic species invasions strongly increased in the twentieth century, probably due to enhanced global ship traffic (Reise et al. 2005). Overall, at least 51 exotic invertebrates, seaweeds, protozoa and phytoplankton have become established in the Wadden Sea (Fig. 2a). Two introduced species, the cordgrass (Spartina anglica) and the Pacific oyster (Crassostrea gigas) have changed, or are about to change, the tidal landscape considerably.

\section{Today's state}

The general state of different species groups today can be summarized as follows (based on Lotze 2005). (1) Mammals: large whales are extinct, small whales are rare, and seals are recovering. (2) Birds: some species are extinct, some are still in decline because of continuing habitat loss, disturbance and pollution, but several species are recovering from their lows in the late nineteenth and early twentieth centuries. (3) Fish: most diadromous species are extirpated or very rare, large groundfish are severely depleted, many inshore and estuarine fish are in decline, and there is high fishing pressure on offshore fish stocks. (4) Invertebrates: in particular, habitat-building species and their associated communities have been lost, and many large, sessile species in the sublittoral have declined, while opportunistic sediment-dwelling species such as polychaete worms in the eulittoral have increased. (5) Plants: sublittoral eelgrass meadows have been lost, and many red algae have declined, whereas opportunistic green algae have increased in recent decades.

\section{Consequences of ecological changes}

The overall consequences of a long history of human impacts on the Wadden Sea is a simplification and homogenization of the species pool, the food web and the ecosystem, as well as their goods and services for society. In the following sections we discuss these consequences in more detail.

\section{Biodiversity}

The number of marine species occurring in the twentieth-century Wadden Sea was estimated at about four marine mammals, 69 species and subspecies of birds, 162 fish, 400 macrobenthic invertebrates $(>1 \mathrm{~mm})$, at least 100 seaweeds, and two seagrasses (von Nordheim et al. 1996). Of these, 144 species $(19.5 \%)$ were listed on the Trilateral Red List, of which 25 (entire area) to 57 (regional/temporal) species were considered extinct in the
Wadden Sea (see Loss and extinctions section above). This loss is opposed by the introduction of at least 51 species. Thus, in terms of simple numbers of species, the Wadden Sea species richness did not change much. However, if we include the severe declines in abundance of all 144 extinct and threatened species, biodiversity has decreased as a result of human impacts. Moreover, species composition has strongly shifted, as can be demonstrated by the bias between species lost and gained (Fig. 2). Losses and declines were severe in mammals $(100 \%$ of species), birds $(30.4 \%)$, fish $(11.7 \%)$, invertebrates $(17.8 \%$, mainly large, sessile or slow-moving species), seaweeds (27\%, mainly red algae), and seagrasses $(100 \%)$, while gains occurred in benthic opportunistic invertebrates (polychaetes, mussels) and green seaweeds. There are also some introduced phytoplankton (Reise et al. 2005), but we do not know whether any extinctions have occurred in this species group.

The general picture that emerges is that mainly large, long-lived, slow-growing and specialized species have been lost or depleted in the Wadden Sea, whereas small, short-lived, fast-growing and generalist species have increased or been introduced. Species depending on special habitats have suffered greatly from habitat loss (e.g. associated communities of oyster banks, eelgrass beds, brackish and shoreline habitats, wetlands) and have been partly replaced by opportunistic species (e.g. polychaetes, green algae). The loss and decline of distinct local or regional communities and the introduction and increase of opportunistic, cosmopolitan species are common features of degraded coastal ecosystems worldwide and contribute to the homogenization of the world's biota (McKinney and Lockwood 1999).

\section{Food-web structure and functioning}

The ecological changes that have occurred in the Wadden Sea (see above) have consequences for food-web structure and functioning. The direction and relative magnitude of changes in food-web components is illustrated in Fig. 4. The most prominent changes are the depletion and loss of large predators (predatory birds, fish, seals, whales) resulting in the loss of upper trophic levels (top predators) in various food chains (Fig. 4). The decrease in top-down control commonly leads to an increase of former prey species and competitors (Daan 1980; Worm and Myers 2003), a trend that is often compensated for by increasing and shifting human exploitation to those species that are lower and lower in the food web (Pauly et al. 1998). Also, the loss of large predators results in the loss of long-term storage and export of organic matter. In contrast, the increase in small, short-lived species enhances the turnover but not necessarily overall production (see paragraph below). Another prominent change in the Wadden Sea food web has been the loss of various specialized species groups on all trophic levels, resulting in the decline of functional diversity and the simplification and homogenization of food-web structure. For 


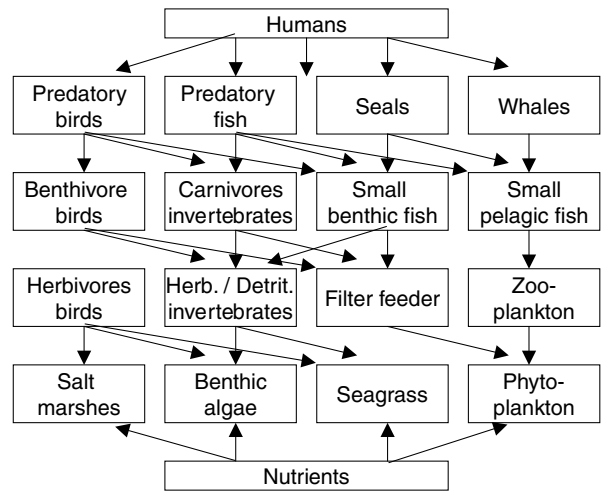

b

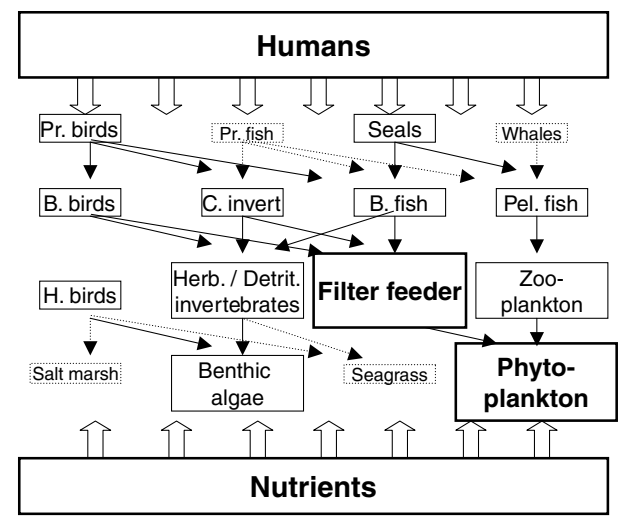

Fig. 4 Conceptual changes in food web structure between more than 1,000 years ago (a) and today (b). The size and line code of boxes and arrows indicate the direction and magnitude of change. Arrows extending to the second or third trophic level (e.g. predatory fish or humans feeding on filter feeders) are not displayed

example, primary production 1,000 years ago was split between salt marshes, seagrasses, benthic macroalgae and microalgae and phytoplankton, while today phytoplankton, benthic microalgae and locally also bloomforming green macroalgae are the main primary producers (Fig. 4; van den Hoek et al. 1979; Asmus et al. 1998). Reduced functional diversity and the loss of higher trophic levels result in reduced niche use, reduced efficiency of energy use and transfer, higher leakage, and as a consequence reduced secondary productivity and biomass (Duffy 2002). Two studies have illustrated the reduction of upper trophic level biomass for the North Sea and North Atlantic. Jennings and Blanchard (2004) used macroecological theory and size spectrum data to predict that current North Sea biomass of large fishes weighing 4-16 and 16-66 kg, respectively is only $2.6 \%$ and $0.8 \%$ of potential biomass in the absence of fisheries exploitation. For the North Atlantic, Christensen et al. (2003) applied ecosystem modeling to fisheries data to estimate that biomass of high trophic-level fishes declined by two-thirds during 1950-1999, and by a factor of nine over the entire century. These estimates, combined with documented declines in other large predators such as birds, seals, and whales, suggest that the sea once supported an abundance of large marine life that is hard to imagine today.
Ecosystem structure and functioning

Species depend not only on prey and predators linked in a food web, but also on habitat availability, water quality and other essential ecosystem properties. In the Wadden Sea, habitat availability, diversity and complexity have been greatly reduced over the past 1,000 years. The landscape and seascape have been simplified and homogenized by large-scale cultivation of agricultural land and elimination of transitional and diverse seafloor habitats (see Habitat change section above). As a consequence, the amount of habitat available for species to breed, spawn, nurse, feed or stage has been reduced. Diminished habitat diversity also causes a lower potential for spreading the risk of survival when populations are faced with extreme events. Another long-term trend is the degradation of water quality through pollutants, toxins, turbidity and anoxia. This has consequences for species health, growth, reproductive abilities and survival. Together, reduced habitat availability and degraded water quality affect the carrying capacity, population growth and recovery of various species.

Declining water quality is also linked to increased eutrophication. High nutrient loads and a reduced estuarine filter and buffer function (e.g. loss of wetlands, seagrass meadows, oyster banks) lead to eutrophication problems, changes in productivity and nutrient cycling (Reise 2005; van Beusekom 2005). Today, primary productivity and organic matter turnover has increased approximately 5-6 fold over pre-industrial levels (van Beusekom 2005). This increased production has led to an increase in algal blooms and opportunistic benthic invertebrates (Beukema et al. 2002), but is not well transferred to higher trophic levels. Leakage of organic matter, high decomposition rates leading to anoxia, and lower denitrification rates are some of the consequences which are common in eutrophied coastal waters worldwide (Cloern 2001). Food-web control probably shifted from a former top-down control dominated by consumers to a bottom-up control dominated by nutrient loads.

\section{Goods and services}

The Wadden Sea ecosystem supported coastal people and societies for millennia, mainly with food, high water quality, natural coastal protection, recreation and resilience. Today, many of these services are reduced or impaired, and many economic opportunities for coastal people have been lost. Until the twentieth century, about 20 different commercial fisheries existed in the Wadden Sea, not to mention opportunities for bird and seal hunting and whaling. After the collapse of most traditional fisheries in the nineteenth and twentieth centuries, only a few commercial fisheries (e.g. blue mussels, cockles, shrimp, flatfish) remain in the Wadden Sea today (Lozan 1994; Wolff 2005). Today, tourism is a more 
profitable economic option for many coastal inhabitants. However, tourism might be negatively affected by changes in water quality, disease outbreaks and harmful algal blooms. Reduction of nutrient loads and restoration of wetlands enhance water quality, and conservation of birds and seals diversifies the opportunities for tourism. Similarly, protection and restoration of benthic habitats and fish stocks will enhance and diversify the goods and services to coastal societies.

Coastal protection is a serious issue to people living around the Wadden Sea. Through diking and draining, humans managed to reduce the risk of floods, to the benefit of coastal people. However, large-scale changes in coastal configuration such as embankments, elimination of flood plains, exploitation of peat lands, a straight dike line, and the transformation of estuaries into shipping canals also enhanced tidal height and the risks of floods (Reise 2005). For example, the extent of devastation induced by the large floods in the fourteenth and seventeenth centuries was caused by peat exploitation and draining, which led to subsidence (Reise 2005). In the twentieth century, tidal range strongly increased in most estuaries, e.g. in the lower Weser River at Bremen from $13 \mathrm{~cm}$ in 1882 to $4.18 \mathrm{~m}$ today (Smetacek et al. 2002; Reise 2005). Today, coastal people have to face and take measures against future consequences of climate change that will increase tidal height and risk of floods even further (Beukema et al. 1990; Reise 2005). Sea level rise, confronted with a defended coastline, will increase turbulence which will decrease sediment stability, and this in turn affects the composition of the benthos in the tidal area (Reise 2005). In its present state, the Wadden Sea may be poorly adapted to absorb the consequences of global change.

\section{Learning from history, or why is this important?}

In this section, we will discuss what we can learn from studying the ecological history of the Wadden Sea and why this is important for conservation, restoration and management, and for public perceptions of the Wadden Sea. We should state, however, that basic sociological and anthropological surveys on people's knowledge, values and perceptions of the Wadden Sea today, its history and changes are lacking, and so the following is based on our own experiences.

\section{Learning from history}

The Wadden Sea has been a highly human-impacted ecosystem for millennia, but this is not obvious to most people living or working in this region, including scientists and managers. Living memory usually reaches back no more than one or two generations, and everything beyond is perceived as part of a mythical past. Today's coastal inhabitants may think of the Wadden Sea they experienced in their youth as "natu- ral', and everything that has happened since as 'change'. Thus the baseline which different generations view as 'natural' is shifting over time. People today may experience the abundance of seals or seabirds as 'unnaturally' high because their numbers were much lower 30 or 50 years ago. But, looking into the past, we see that most populations may be far from their former abundance and carrying capacity (see Lotze 2005). On the other hand, people living today are used to the absence of large fish and the absence of diverse benthic and wetland habitats in the Wadden Sea because they have never experienced the richness of former centuries, and the greatest changes occurred before their lifetime. In recent decades, pollution, eutrophication and climate change have been judged as serious environmental issues, because they are happening now and have direct consequences for humans. Long-term overexploitation and habitat loss are rarely seen as the major underlying drivers of long-term changes. In contrast, history can provide us with a long-term perspective on the current state of the Wadden Sea, a baseline of what was 'natural' in the past, and a vision of what might be possible again in the future. It also provides an understanding of long-term ecosystem changes and its drivers. All of these can help to formulate new goals, visions and awareness for conservation, restoration and management.

There are many gaps and uncertainties in our past picture of the Wadden Sea. To fill these gaps and confirm our view of the past, we may compare the Wadden Sea with similar soft-sediment coastal ecosystems around the world, e.g. the Banc d'Arguin in Mauritania, Africa (Campredon 2000). Although this area lacks barrier islands, the basic physical features of the two systems are similar. However, the Banc d'Arguin ecosystem is different. For example, the extent of the tidal flats in Banc d'Arguin is less than $15 \%$ of those in the Wadden Sea, but they provide habitat and food for peak numbers of up to 2 million waterbirds compared to 1 million in the Wadden Sea (Wolff and Smit 1990). Moreover, macrofauna species richness is much higher than in the Wadden Sea (e.g. approx. threefold for macrobenthic invertebrates; Wolff, unpublished data), and large vertebrates such as flamingos (Phoenicopterus ruber), pelicans (Pelecanus onocrotalus) and bottlenose dolphins (Tursiops truncatus) are numerous. Until recently, this also applied to large sharks and rays. On the other hand, benthic invertebrate biomass is 3-5 times higher in the Wadden Sea and often dominated by a few small species (Michaelis and Wolff 2001). The most important primary producers in the Banc d'Arguin are seagrasses (Zostera noltii, Cymodocea nodosa). The human population of about 2,000 people in the area was traditionally engaged in fishing mullets (Mugil cephalus) but in the past 20 years fishing has shifted to a variety of sharks and rays. In light of the evidence compiled in this volume, we propose that the Banc d'Arguin system may give us an idea of how the Wadden Sea may have looked, and how it may have functioned in the past. 
Fundamental versus reversible changes

Change is a fundamental principle of life. The Wadden Sea, as any other ecosystem, is not static and underlies constant abiotic and biotic changes. Change itself created the Wadden Sea in the first place some 7,500 years ago. Since then, natural forces have shaped life in the Wadden Sea for millennia, and early coastal people and societies adapted to the changing environment. Over the last 2,500 years, however, human-induced changes have increased and gradually gained dominance in influencing the structure and functioning of the Wadden Sea ecosystem. The ecological history of the Wadden Sea can help us to understand which of these human-induced changes are fundamental and which are reversible, in order to develop sound management strategies for the future.

Species extinctions are irreversible. However, some species are only extirpated regionally and could return or be re-introduced if their basic living conditions are still in place or restored (see Wolff 2000b). This has already occurred naturally for several species such as the grey seal (Halichoerus grypus), the white-tailed eagle ( $\mathrm{Ha}$ liaeetus albicilla) and great white egret (Egretta alba), that were extirpated temporally and re-colonized the Wadden Sea from adjacent regions after decades to centuries (see Wolff 2000b; Lotze 2005). Because most species extinctions and severe declines were caused by overexploitation and habitat change, these are the two major human impacts that should be reduced in order to allow recovery and reverse population declines. Overexploitation is reversible. Gear regulations in favour of less destructive and more selective gear would reduce bycatch, habitat destruction and the catch of unwanted size or age classes. Reduced fishing quotas would allow depleted stocks to re-build. And marine protected areas or no-take zones would allow species to find a refuge, habitats to recover, and diversity to build up (FSBI 2001). Habitat loss and destruction is partially reversible. Some habitats may be lost forever or may take centuries to millennia to recover (e.g. peatlands). Others, however, such as wetlands and coastal lagoons, could be partially restored, for which successful examples exist (e.g. Hinz 1992; Rudfeld 1992; Hötker 1994). The restoration of shoreline dynamics is important for supporting species of the mostly ephemeral and narrow habitats in the transition zone between the land and the sea. Restoration and recovery of Sabellaria reefs, eelgrass meadows, and maybe even oyster banks could be possible if bottomtrawling were reduced and water quality improved [e.g. for eelgrass (van Katwijk 2003)]. However, recovery of species and habitats may take decades to centuries and may not be possible for all species. But positive examples exist for seals and many coastal birds (Lotze 2005). The introduction of exotic species is usually irreversible once the invader has established wild populations. However, measures can be taken to prevent further introductions (Reise et al. 2005).

Other human-induced changes include the transformation of the coastline, which has been straightened and fixed. This could be partially reversed to allow for a more dynamic response by the Wadden Sea coast towards rising sea levels in the course of climate change (e.g. Hekstra 1990). Pollution and eutrophication have strong negative consequences for the Wadden Sea ecosystem. Some pollutants persist in sediments or organisms and will have long-term effects on species health, survival or reproductive ability that cannot easily be reversed. But, pollution and nutrient loads can be reduced by implementing better waste-water treatment plants, by avoidance of (and implementing better recycling of) waste products, reducing land run-off and fertilizer use, and by banning highly toxic or otherwise harmful substances. Some of these measures have already been implemented and have shown success, e.g. the ban of DDT and the reduction of nutrient loads (Wolff 1992; De Jonge et al. 1993; van Beusekom 2005).

Another largely irreversible trend is the massive increase in human population living around, depending upon, or otherwise using the Wadden Sea, especially since the Middle Ages. However, people can alter their habits and ways of interacting with and influencing the Wadden Sea, and their ideas of what is important. This has, to some degree, already occurred, as when conservation efforts increased in the twentieth century and people started to value species, habitats and nature in ways other than for exploitation. Still, change is often perceived as negative and destructive. But, if the goal is to restore a more natural ecosystem, then the Wadden Sea should be allowed to change again and become the dynamic, evolving system that it once was.

\section{Conservation and management}

The general problems in the Wadden Sea are the loss of species, the simplification of food-web and habitat diversity, the depletion and extinction of large consumers, the homogenization of the landscape and seascape, and the degradation of water quality. These ecological changes have also reduced the goods and services that the Wadden Sea once provided to society. Improving this situation requires diversification, protection, restoration and recovery of natural features, and with that also economic and cultural opportunities. Measures that could be taken to reverse negative trends were outlined in the previous section, which is by a long way incomplete. And success stories of recovery and restoration that exist in the Wadden Sea and other areas could be used to select the options that are potentially most successful. What we want to stress here, however, is that although we now know a lot about the past Wadden Sea ecosystem and the drivers of change, we may not necessarily be able to predict and control recovery or the outcome of conservation measures taken. Conservation should be seen as an ecosystem experiment. As a coastal society, we could try different measures, allow for errors to happen, and learn from experience. Different measures could be used in different regions, and they should 
be implemented step by step. Conservation should be part of an Integrated Coastal Zone Management Plan that attempts to integrate the objectives of different interest groups around the Wadden Sea.

\section{Conclusions}

The Wadden Sea ecosystem has been changed by human impacts over millennia. In an interdisciplinary effort that integrates archaeological, historical and recent scientific data, we have tried to reconstruct the ecological history of this unique coastal ecosystem. What was new and surprising to most of us was: (1) the very early start of human impacts and signs of ecological changes (about 2,500 years ago); (2) that the peak of depletion of most traditionally used living resources was in the late nineteenth/early twentieth century; and (3) that a large number of species extinctions and declines had a very well aligned causality, with habitat transformation and exploitation as the main drivers.

This history of change is not unique to the Wadden Sea. Recent efforts to uncover the history of the ocean worldwide revealed similar patterns of serial resource depletion, large-scale habitat destruction, and degradation of water quality (Jackson et al. 2001; Myers and Worm 2003; Griffiths et al. 2004; Lotze and Milewski 2004). These global changes are interlinked and partly driven by the general development of the human population and its technologies in Europe and around the globe (see Hoffmann 1996, 2005; Lotze 2004). Of course the same developments have also dramatically changed most terrestrial ecosystems (Hughes 2001).

Knowing about the ecological history of the Wadden Sea and other ecosystems is important, because similar changes are still occuring in other parts of the world. We have just begun to understand how profoundly humans have affected the seas, and how dramatic the consequences for the ecosystems and societies have been. In the Wadden Sea, the coastal society that depended on agriculture and a large variety of fisheries and hunting for centuries experienced a cultural and economic collapse in the nineteenth and twentieth centuries. It shifted from a diverse resource-based economy to a servicebased economy. The current resilience of the Wadden Sea ecosystem and society to environmental change is probably low. However, what history can also teach us is that longstanding changes can be reversed when action is taken. Diversification, restoration and recovery of species and habitats are needed to bolster the resilience of the Wadden Sea ecosystem and society against future environmental change.

Acknowledgements We gratefully acknowledge financial support for the interdisciplinary workshop on the Ecological History of the Wadden Sea under the Census of Marine Life's History of Marine Animal Populations Project by the Sloan Foundation, the Alfred Wegener Institute for Polar and Marine Research, and the MARINERS Program of Southern Denmark University.

\section{References}

Asmus R, Jensen MH, Murphy D, Doerffer R (1998) Primärproduktion von Mikrophytobenthos, Phytoplankton und jährlicher Biomasseertrag des Makrophtobenthos im SyltRømø Wattenmeer. In: Gätje C, Reise K (eds) Ökosystem Wattenmeer: Austausch, Transport und Stoffwandlungsprozesse. Springer-Verlag, Berlin Heidelberg New York, pp 367-392

Bantelmann A (2003) Nordfriesland in vorgeschichtlicher Zeit, vol 19. Schriftenreihe des Dr.-Carl-Häberlin-Friesen-Museums Wyk auf Föhr, NS

Bauer KM, Glutz von Blotzheim UN (1966) Handbuch der Vögel Mitteleuropas. Akademische Verlagsges, Frankfurt am Main, Germany

Beukema JJ, Wolff WJ, Brouns JJWM (1990) Expected effects of climatic change on marine coastal ecosystems. Kluwer Academic Publishers, Dordrecht, The Netherlands

Beukema JJ, Cadée GC, Dekker R (2002) Zoobenthic biomass limited by phytoplankton abundance: evidence from parallel changes in two long-term data series in the Waddden Sea. J Sea Res 48:97-110

van Beusekom JEE (2005) A historic perspective on Wadden Sea eutrophication. Helgol Mar Res (in press)

Billén G, Garnier J (1997) The Phison River plume: coastal eutrophication in response to changes in land use and water management in the water shed. Aquat Microb Ecol 13:3-17

Camphuysen CJ, Berrevoets CM, Cremers HJWM, Dekinga A, Dekker R, Ens BJ, van der Have TM, Kats RKH, Kuiken T, Leopold MF, van der Meer J, Piersma T (2002) Mass mortality of common eiders (Somateria molissima) in the Dutch Wadden Sea, winter 1999/2000: starvation in a commercially exploited wetland of international importance. Biol Cons 106:303-317

Campredon P (2000) Between the Sahara and the Atlantic. Banc d'Arguin national park, Mauritania. Fondation International du Banc d'Arguin, Arles, France

Christensen V, Guenette S, Heymans JJ, Wlaters CJ, Watson R, Zeller D, Pauly D (2003) Hundred-year decline of North Atlantic predatory fishes. Fish Fish 4:1-24

Cloern JE (2001) Our evolving conceptual model of the coastal eutrophication problem. Mar Ecol Prog Ser 210:223-253

Daan N (1980) A review of replacement of depleted stocks by other species and the mechanisms underlying such replacement. Rapp P-v Reun Cons int Explor Mer 177:405-421

De Jonge VN (1983) Relations between annual dredging activities, suspended matter concentrations and the development of the tidal regime in the Ems estuary. Can J Fish Aquat Sci 40:289-622

De Jonge VN, de Jong DJ (2002) "Global change" Impact of interannual variation in water discharge as a driving factor to dredging and spoil disposal in the river Rhine system and of turbidity in the Wadden Sea. Est Coast Shelf Sci 55:969-991

De Jonge VN, Essink K, Boddeke R (1993) The Dutch Wadden Sea: a changed ecosystem. Hydrobiologia 265:45-71

De Smet WMA (1981) Evidence of whaling in the North Sea and English Channel during the Middle Ages. FAO Fish Ser 5(3):301-309

Duffy JE (2002) Biodiversity and ecosystem function: the consumer connection. Oikos 99:201-219

van Eerden MR (1997) Long-term changes in wetland area and composition in the Netherlands affecting the carrying capacity for wintering water birds. In: van Eerden MR (ed) Patchwork, patch use, habitat exploitation and carrying capacity for water birds in Dutch freshwater wetlands. Ph.D. thesis, Rijksuniversiteit Groningen, Groningen, The Netherlands, pp 3156

FSBI (2001) Marine protected areas in the North Sea. Briefing Paper 1, Fisheries Society of the British Isles. Granta Information Systems, Sawston, Cambridge, UK

Griffiths CL, van Sittert L, Best PB, Brown AC, Clark BM, Cook PA, Crawford RJM, David JHM, Davies BR, Griffiths MH, Hutchings K, Jerardino A, Kruger N, Lamberth S, Leslie R, 
Melville-Smith R, Tarr R, van der Lingen CD (2004) Impacts of human activities on marine animal life in the Benguela: a historical overview. Oceanogr Mar Biol Annu Rev 42:303-392

Haywood J (1997) Atlas of world history. Andromeda Oxford, Abingdon, Oxfordshire, UK

Hekstra GP (1990) Man's impact on atmosphere and climate: a global threat? Strategies to combat global warming. In: Beukema JJ, Wolff WJ, Brouns JJWM (eds) Expected effects of climatic change on marine coastal ecosystems. Kluwer Academic Publishers, Dordrecht, The Netherlands, pp 5-16

Hinz V (1992) Embankments in the German Wadden Sea-from landreclamation and agriculture to saltwater lagoons and nature conservation. Neth Inst Sea Res Publ Ser 20:253-256

van den Hoek C, Admiraal W, Colijn F, De Jonge VN (1979) The role of algae and seagrasses in the ecosystem of the Wadden Sea: a review. In: Wolff WJ (ed) Flora and vegetation of the Wadden Sea. Balkema, Rotterdam, pp 9-118

Hoffmann RC (1996) Economic development and aquatic ecosystems in Medieval Europe. Am Hist Rev 101:631-669

Hoffmann RC (2005) A brief history of aquatic resource use in Medieval Europe. Helgol Mar Res (in press)

Holm P (2005) Human impacts on fisheries resources and abundance in the Danish Wadden Sea, c1520 to the present. Helgol Mar Res (in press)

Hötker H (1994) Wadden Sea birds and embankments - can artificial wetlands compensate for losses due to land claims? Ophelia Suppl 6:279-295

Hughes JD (1996) Pan's travail. Environmental problems of the ancient Greeks and Romans. John Hopkins University Press, Baltimore, London

Hughes JD (2001) Environmental history of the world: humankind's changing role in the community of life. Routledge, London

Huntley B, Baillie M, Grove JM, Hammer CU, Harrison SP, Jacomet S, Jansen E, Karlen W, Koc N, Luterbacher J, Negendank J, Schibler J (2002) Holocene paleoenvironmental changes in north-west Europe: climatic implications and the human dimension. In: Wefer G, Berger W, Behre K-E, Jansen E (eds) Climate development and history of the North Atlantic realm. Springer, Berlin Heidelberg New York, pp 259-298

Jackson JBC, Kirby MX, Berger WH, Bjorndal KA, Botsford LW, Bourque BJ, Bradbury RH, Cooke R, Erlandson J, Estes JA, Hughes TP, Kidwell S, Lange CB, Lenihan HS, Pandolfi JM, Peterson CH, Steneck RS, Tegner MJ, Warner RR (2001) Historical overfishing and the recent collapse of coastal ecosystems. Science 293:629-638

Jennings S, Blanchard JL (2004) Fish abundance with no fishing: predictions based on macroecological theory. J Anim Ecol 73:632-642

van Katwijk MM (2003) Reintroduction of eelgrass (Zostera marina L.) in the Dutch Wadden Sea: a research overview and management vision. In: Wolff WJ, Essink K, Kellermann A, van Leeuwe MA (eds) Challenges to the Wadden Sea Area. Proceedings of the 10th international scientific Wadden Sea symposium, Groningen, The Netherlands, 31 October-3 November 2000, pp 173-195

Knottnerus OS (2005) History of human settlement, cultural change and interference with the marine environment. Helgol Mar Res (in press)

Lotze HK (2004) Repetitive history of resource depletion and mismanagement: the need for a shift in perspective. In: Browman H, Stergiou K (eds) Perspectives on ecosystem-based approaches to the management of marine resources. Mar Ecol Prog Ser 274:282-285

Lotze HK (2005) Radical changes in the Wadden Sea fauna and flora over the last 2,000 years. Helgol Mar Res (in press)

Lotze HK, Milewski I (2004) Two centuries of multiple human impacts and successive changes in a North Atlantic food web. Ecol Appl 14:1428-1447
Lozan JL (1994) Zur Geschichte der Fischerei im Wattenmeer und in Küstennähe. In: Lozan JL, Rachor E, Reise K, von Westernhagen H, Lenz W (eds) Warnsignale aus dem Wattenmeer. Blackwell, Berlin, pp 215-226

Magnus O (1555) Description of the northern peoples. Hakluyt Society London 1998, Rome 1555

McKinney ML, Lockwood JL (1999) Biotic homogenization: a few winners replacing many losers in the next mass extinction. Trends Ecol Evol 14:450-453

Michaelis H, Wolff WJ (2001) Soft-bottom fauna of a tropical (Banc d'Arguin, Mauritania) and a temperate (Juist Area, German North Sea Coast) intertidal area. In: Reise K (ed) Ecological comparisons of sedimentary shores. Ecol Stud 151. Springer, Berlin, pp 255-274

Myers RA, Worm B (2003) Rapid worldwide depletion of predatory fish communities. Nature 423:280-283

von Nordheim H, Andersen ON, Thissen J (1996) Red lists of biotopes, flora and fauna of the trilateral Wadden Sea area, 1995. Helgol Meeresunters 50(Suppl):1-136

Pauly D, Christensen V, Dalsgaard J, Froese R, Torres F Jr (1998) Fishing down marine food webs. Science 279:860-863

Plinii Secundi C (1513) Naturalis historiae. Libri XXXVII, Liber $\mathrm{X}$, Venice, Italy

Prummel W, Heinrich D (2005) Archaeological evidence of former occurrence and changes in fishes, amphibians, birds, mammals and molluscs in the Wadden Sea area. Helgol Mar Res (in press)

Reijnders PJH (1986) Reproductive failure in common seals feeding on fish from polluted coastal waters. Nature 324:456-457

Reijnders PJH (1992) Retrospective population analysis and related future management perspectives for the harbour seal Phoca vitulina in the Wadden Sea. Neth Inst Sea Res Publ Ser 20:193-197

Reise K (2005) Coast of change: habitat loss and transformations in the Wadden Sea. Helgol Mar Res (in press)

Reise K, Herre E, Sturm M (1989) Historical changes in the benthos of the Wadden Sea around the island of Sylt in the North Sea. Helgol Meeresunters 43:417-433

Reise K, Dankers N, Essink K (2005) Introduced species. In: Essink K, Dettmann C, Farke H, Laursen K, Lüerßen G, Marencic H, Wiersinga W (eds) Wadden Sea quality status report 2005. Wadden Sea Ecosystem. Common Wadden Sea Secretariat, Wilhelmshaven, Germany (in press)

Rudfeld L (1992) The Danish Wadden Sea-25 years of protection. Neth Inst Sea Res Publ Ser 20:199-213

Smetacek V, Wefer G, Alheit J, Lamy F, Kraker Ad, Flemming B, Lindeboom H, Streif H, Weering Tv, Storch Hv (2002) Climate and human induced impacts on the coastal zone of the southern North Sea. In: Wefer G, Berger W, Behre K-E, Jansen E (eds) Climate development and history of the North Atlantic Realm. Srpinger-Verlag, Berlin Heidelberg Germany, pp 473-486

Vollmer M, Guldberg M, Maluck M, Marrewijk D, Schlicksbier G (2001) Landscape and cultural heritage in the Wadden Sea region-project report. In: Wadden Sea Ecosystem No. 12. Common Wadden Sea Secretariat, Wilhelmshaven, Germany, $\mathrm{p}$ 336

Wolff WJ (1992) Ecological developments in the Wadden Sea until 1990. Neth Inst Sea Res Publ Ser 20:23-32

Wolff WJ (2000a) Causes of extirpations in the Wadden Sea, an estuarine area in The Netherlands. Cons Biol 14:876-885

Wolff WJ (2000b) The south-east North Sea: losses of vertebrate fauna during the past 2000 years. Biol Cons 95:209-217

Wolff WJ (2005) The exploitation of living resources of the Dutch Wadden Sea: a historical overview. Helgol Mar Res (in press)

Wolff WJ, Smit CJ (1990) The Banc d'Arguin as an environment for coastal birds. Ardea 78:17-38

Worm B, Myers RA (2003) Meta-analysis of cod-shrimp interactions reveals top-down control in oceanic food webs. Ecology $84: 162-173$ 